\title{
China's Outward Foreign Direct Investment in Africa: How are Ghana Benefiting and its Issues on the Economy?
}

\section{Yeboah Evans ${ }^{1}$ Agyeiwaah Vivian Antwi ${ }^{2}$}

${ }^{1,2}$ Nanjing University of Science and Technology, China. Email: Yeboahevans.56@yahoo.com Tel: +233543231956

'Email:Vivianantwi722@gmail.comTel:+393396321307

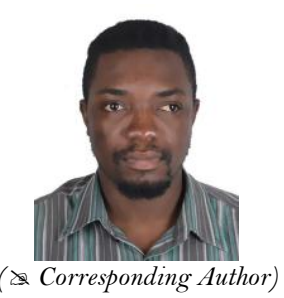

Abstract

As more nations continue to embrace foreign direct investment (FDI) inflow to enhance economic development, China has increased its outward foreign direct investment on the African continent of which most countries have benefited from it with Ghana not an exemption. To investigate whether China is contributing significantly to the number of projects by foreign investors over the years, the total number of FDI registered projects by the top investing countries within the Ghanaian economy were considered. This paper makes use of quantitative analysis through a descriptive statistical approach based on the data generated from the Ghana Investment Promotion Centre (GIPC) between 2013 and 2018. It was revealed that, China's contribution to the total number of FDI registered projects is very significant, but the estimated cost of these Chinese projects is lower. However, Chinese investment is mostly found in the manufacturing sector of the Ghana's economy. It is suggested that, as the government prepares to roll out on the one-direct-one factory initiative, sound investment policies should be established to protect these infant industries and promote outward FDI.

Keywords: FDI, Economy, Projects, Ghana, Cost, China.

Citation | Yeboah Evans; Agyeiwaah Vivian Antwi (2019). China's Outward Foreign Direct Investment in Africa: How are Ghana Benefiting and its Issues on the Economy? Economy, 6(1): 34-40. History:

Received: 2 May 2019

Revised: 7 June 2019

Accepted: 18 July 2019

Published: 16 September 2019

Licensed: This work is licensed under a Creative Commons Attribution 3.0 License $($ co)

Publisher: Asian Online Journal Publishing Group
Acknowledgement: Both authors contributed to the conception and design of the study

Funding: This study received no specific financial support

Competing Interests: The authors declare that they have no conflict of interests.

Transparency: The authors confirm that the manuscript is an honest, accurate, and transparent account of the study was reported; that no vital features of the study have been omitted; and that any discrepancies from the features of the study have been omit
study as planned have been explained.

study as planned have been explained.
Ethical: This study follows all ethical practices during writing.

\section{Contents}

1. Introduction

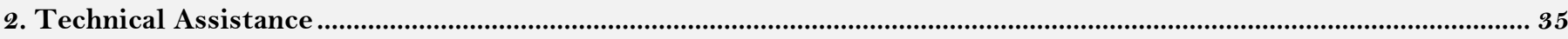

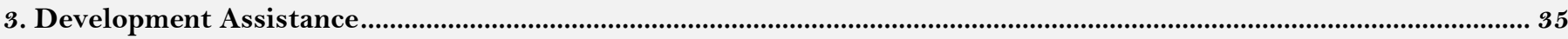

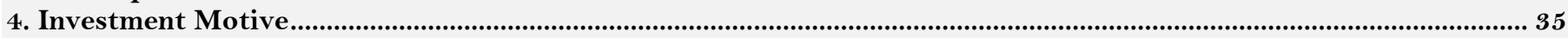

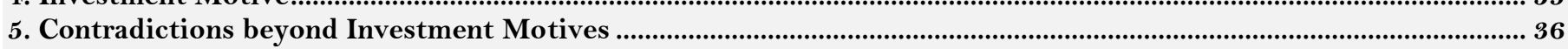

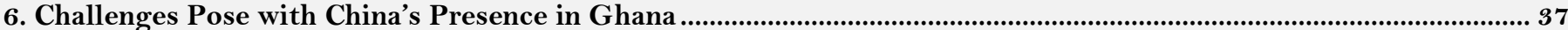

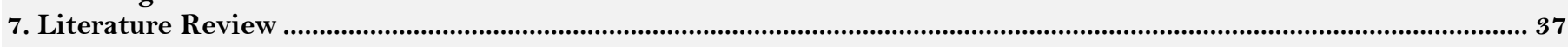

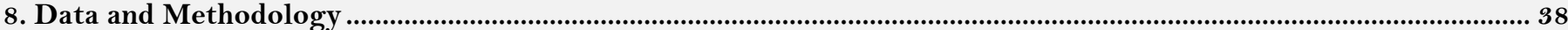

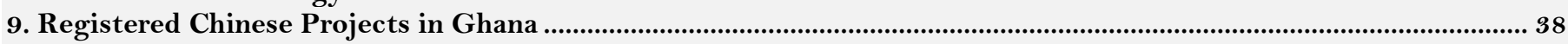

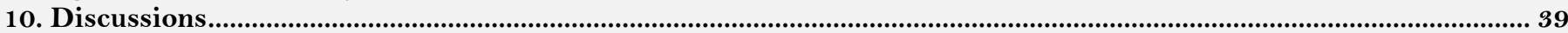

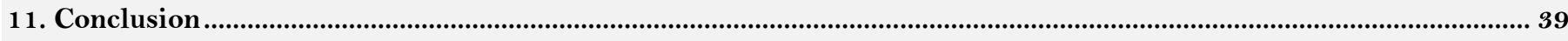

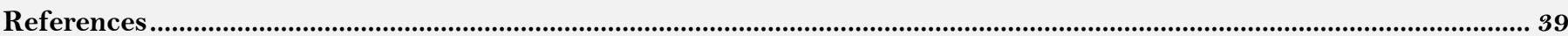




\section{Contribution of this paper to the literature}

This study contributes to existing literature by investigating whether China is contributing significantly to the number of projects by foreign investors over the years; the total numbers of FDI registered projects by the top investing countries within the Ghanaian economy were considered.

\section{Introduction}

China's outward foreign direct investment on the African continent has grown massively over the past years. In 2003, China's total OFDI to Africa stood at US\$74.8 million (Claassen et al., 2012). As foreign direct investment outshines foreign aid, China still provides most nations with aids which comes in the forms of providing most rural areas and villages access to potable water in Africa. China's foreign aid to Ghana cuts across infrastructural development, education and agriculture, cooperation in infrastructural development appears to have been more welcomed by Ghana due to Ghana's estimated \$2.5 billion infrastructure deficit in financing (Davies et al., 2008). The official discretionary ties between Ghana and China has been portrayed by regular level of visits, cultural/educational exchanges, economic cooperation and development aids provisions. The majority of African countries provided significant support for China before its economic reform began in 1979. These ranges from the Congolese donating a huge amount of money in building a school in a rural community under the Shanghai municipality as well as many African leaders cast their vote to help China's membership under the United Nations General Assembly. In the early 2000s, China has brought forth many initiatives and policies to strengthen its cooperation with Africa. There has been a massive and continuous movement of Chinese investment and companies in African countries, especially in the area of raw materials extraction , such as mining and textiles, oil and gas, and infrastructure development (Broadman, 2007). Ghana has benefited significantly from China's outward foreign direct investment which ranges from trade-investment, technical and development assistance. Currently China has the highest number of foreign direct investment registered projects among the other investing nations in the Ghanaian economy. During the during the first $\left(1^{\text {th }}\right)$ quarter of 2012 , the center reordered a total of 95 new projects registered with a total estimated value of $\$ 1.18$ billion, the estimated value represented an increase of $212.35 \%$ compared to the value recorded in the same quarter of 2011 (Ghana Investment Promotion Centre, 2012). China topped the top ten (10) investing countries in Ghana with 12 new registered projects in the fourth quarter of 2012. This paper is targeted on both positive and negative influences of Chinese investment in Ghana.

\section{Technical Assistance}

The various public sectors have enjoyed some advantages as an outcome of Chinese investment in the Ghanaian economy. These benefits range from fisheries, education, training, communication, energy and agriculture. Under the education benefits are wide range of scholarship offers to Ghanaians and other countries in Africa to study in China from bachelors to the PHD level. Example of scholarships enjoyed by Ghanaians are Chinese government Scholarship, Municipal and local government, and University scholarships. Ghanaians and countries on the African continent do not benefit from the One Belt One Road initiative scholarship as it is purposely for countries part of this initiative. However, other educational exchange programs for technical assistance cut across personnel, equipment and training which aids in the improvement of various sectors in Ghana. Bui Hydro-electric power dam projects in the energy sector and support for irrigation farming, which includes Afire rice project in the Volta region are some of the projects under technical cooperation between China and Ghana. The National Communications Backbone Network Project was the recipient of a USD 32 million financing package to finance phase one of the project in 2007, which aims to link the various regional capitals and other major towns with telecommunications access (ACET, 2009).

\section{Development Assistance}

Ghana's economic growth recorded over the past two decades has been among the strongest in Africa at around 4.5 per cent annually and growth accelerated to about 5.3 per cent in 2000-03, rose further to 5.8 per cent in 2004 and to an estimated 5.9 per cent in 2005 (OECD, 2006). However, there was a serious economic crisis in 2016, but as a result of good economic fundamentals and sound policies, the economy of Ghana attained a massive growth in 2017. Loans and investment from China has been a substantial factor in the development of the country. Major notable completed public sector projects with Chinese aid in building and construction sector entails: US $\$ 15$ million office complex building for the Ministry of Foreign Affairs and Regional Integration, US\$622 million development of the Bui Hydro-Electric power dam, US\$ 28 million constructions of $17 \mathrm{~km}$ Ofankor-Nsawam road network, and US\$ 6 billion Ghana Railway Project (Kwasi and Li, 2016). Bauxite barter agreement between China and Ghana of US $\$$ 2billon to build the country's infrastructure with bauxite. The agreement among others, will fund infrastructure projects in Ghana, including roads, bridges, interchange, hospitals, housing, railway development as well as rural electrification ${ }^{1}$.

\section{Investment Motive}

For multinational companies, the ultimate aim and common encouragement to invest in other countries is maximizing output. Using the typology of foreign direct investment which was developed by Jere Behrman to explain the different motives of FDI under OLI theory. There were four objectives of FDI, which includes resource seeking, market seeking, efficiency seeking and strategic asset/capabilities seeking. Resource seeking investment happens rapidly when there is an insufficient capital base to develop a vast stock of resources or when there is a shortage of skilled labor and professional knowledge (UNCTAD, 1998). Multinational companies, individuals and governments invest in other nations for the purpose of seeking and securing natural resources such minerals (Gold, diamond, bauxite, aluminum etc.), raw materials and cheaper labor cost. With the abundance of natural resources 
and availability of skilled and unskilled labor, investors turn to exploit these resources with the intention of reexporting to the parent country or for the host country's consumption. China and other developed countries are investing heavily on the African continent and in Ghana for the access to these resources.

Market seeking has become one of the ultimate motive investors consider when investing abroad. Population size, income and the purchasing power of the people are taken into account. The special regions on the African continent are often used as a medium of getting access to other market within these zones. Chinese investors in Ghana can gain access to the West Africa sub-region common market as an outcome of Ghana being a member of the Economic Community of West African States. However, as more and more Ghanaians developing a special taste and preference for a commodity or a product induce investors to establish a subsidiary company abroad for its consumers. With the majority of the People developing much interest in made in China phones and other manufactured products have influenced many Chinese companies investing in the Ghanaian economy.

Efficiency seeking, most investors consider the ultimate ways of becoming more productive. The restructuring of its already existing investment in order to attain an efficient allocation of global economic activities of companies. The motive brings about global specialization whereby organizations and firms seek to gain from the difference in product and factor price variegate risk. The intention of the efficiency-seeking MNE is to take advantage of different factor endowments, cultures, institutional arrangements, economic systems and policies, and market structures by concentrating production in a limited number of locations to supply multiple markets (Dunning, 1993).

Strategic asset/capabilities seeking, this where investors such as multinational firms pursue the agenda of strategic operations for the acquisition of existing companies or assets so as to protect specific superiority with the aim of advancing its international competitive posture. These acquisitions can be of some key domestic established firms, local capabilities (R\&D, knowledge and human capital), market knowledge and pre empting market entry by competitors.

\section{Contradictions beyond Investment Motives}

As many developed economies turn to influence most developing nations and least developed countries, several funds and development projects are packaged in the form of foreign direct investment. Initially, China's major trading partners were the United States and the European Union, but during this era, there has been a new sense of direction of which China is investing heavily in Africa. According to the United Nations Conference on Trade and Development (UNCTAD) world investment report in 2017 indicated that, the United States, United Kingdom and France remain the top three investors economies by FDI stock in Africa. However, China is ranked as the top four investing nations and, between 2010 and 2015 the percentage change in the rate at which the top three (3) investing countries investment were growing in terms of value weighed lower than the Chinese. The value of Chinese investment increased at the rate of 269.2 percent between 2010 and 2015 . With regards to the recent ways of investment by countries goes beyond the normal investment motives. China's investment on the African continent has been focused mostly on mineral deposits. For instance, China is investing in minerals in countries like Zimbabwe, Zambia and Ghana. Ghana recently agreed on a barter agreement on bauxite with China for infrastructural development projects. Conversely, some of the motives which could go beyond the proposed FDI motives by Dunning and other researches includes political influence, gaining domination over developing and least developed countries, and over exploitation of natural resources.

Political influence happens when one country can exert pressure on another country to control its decisions. As many nations develop bilateral relationships among each other for economic and security benefits. However, nations also form allies for protection purpose and security threats. Foreign investing countries, international financial institutions, donor's clubs and international monetary fund (IMF) do exercise influence on the least developed and developing countries economic and development decisions which affect the distribution and allocation of certain vital FDI projects within their economies. Apparently, China also do exercise some political pressure through its outward foreign direct investment in Africa. China recently started building military base in some African countries.

Conversely, the over dependence of most African nations on foreign direct investment inflows without pursing outward foreign direct investment turn to give them less advantages on the other continent. Through FDI many developed economies turn to manipulate most African leaders. As a result of many FDI packages coming in the form of loans, these investing nations applied strict conditions attached, whereas most African leaders end up not being able to fulfil the terms and conditions involved. Considering the mining sector of Ghana, almost all the mining companies are foreign owned businesses. Ghana's percentage share from gold mines is way lower than its supposed to enjoy as the ownership of these mineral resources and the same applies to the crude oil being drill on the Jubilee field. There is a notion that, many African leaders fear of not getting loans from the developed countries, China and India if they fail to comply and conform to their rules. According to Mr. Di Maio, "France is one of those countries that by printing money for 14 African states prevents their economic development and contributes to the fact that refugees leave and die in the sea or arrive on our coast"2

Gaining domination, the hypothetical power formation which attained or desired to, of which a strong single political hegemony posses power over some countries across the globe. The political fiction, where it postulates that some group of people or nations have achieved this objective in a secret way. This domination is currently happening on the African continent as most developed countries such as the United States of America, France, Germany, the United Kingdom etc.as well as developing nations such as China and India expanding their authorities in many countries in Africa who have become subservient to it. As technology becomes a new set of modern development in the world turns to induce many countries in Africa to embark on a technological advancement in their various economies. Today no technological hindrance persists in the path of a global empire as modern technology has made it possible to extend the control of mind and actions to every corner of the globe regardless of geography and climate changes (Alfred, 1967). During the early $17^{\text {th }}$ century, Sir Walter Raleigh

${ }^{2}$ https://www.bbc.co.uk/news/amp/world-europe-46955006 
came out with a proposal that world domination could be attained through control of the ocean, stating that "whosoever command the sea commands the trade: whosoever commands the trade of the world command riches of the world, and consequently the world itself (Sir, 1829). Conversely, China is controlling the world through its exports of manufactured products and technology, thereby commanding riches from its trading partners. As part of the major world leading economies such as China and the US motives to control the world economy through FDI, international trade and determining global market prices of certain vital commodities turns to affect many least developed and some developing nations. Over dependence on the US dollar affects import and export by most businessmen and women in Africa.

Over exploitation of natural resources, a major factor for African countries to achieve a great benefit from FDI inflows is as a result of the abundance of its natural resources. One main favored position of numerous African nations for drawing in FDI is their natural resources (Unctad, 2007). An exploitation of natural resources contributes significantly to a country's economic and development. However, over exploitation of these resources come with many adverse impacts on an economy. With the recent aggressiveness of many Chinese in Ghana in search of gold has led to several illegal mining activities. This illegal gold mining has resulted in major environmental issues such as changing of productive land into mining zones, pollution of air, water and land, and degradation of fertile soils which affect ecology and climate.

\section{Challenges Pose with China's Presence in Ghana}

There are negative effects which comes along with the inflow of foreign direct investment from China. Loans from China to Ghana comes with conditions attached which in the short run have a constructive outcome for the administration of Ghana and a negative effect over the long run. The Beijing Summit in 2006 increased the interaction between China and Africa even further, as the both sides agreed to accelerate cooperation, especially in seam resources examination and utilization. As indicated by the Ghanaian government projections of oil costs, Ghana with end up paying US\$ 6.4 billion to China for the US\$ 3 billion credit, or should give away 750 million barrels of the nation's raw petroleum to a Chinese company for more than 15 years. Consequently, the development and technical assistance as in the form of investment also comes with conditions attached to them, thereby raising concerns about how to refinance these loans in a profitable way without societal costs in the long run (Joseph, 2015). Another example of an investment with major conditions attached is the dam funding deal, where natural resources such as cocoa will be used to pay for the cost of credit (Reuters, 2007). Conversely, like other African countries such as South Africa and Nigeria, Ghana's manufacturing sector is missing out on the opportunities for trade with China. Because of increasing Chinese business and investment with majority shareholder control, the industrial sector is being challenged by the continuous and rising import of manufactured goods (Joseph, 2015). The relationship between China and the African continent through China-Africa cooperation has ultimately received many criticisms from international observers. China's foreign policies in the direction of African nations of weakening universal struggles to expand transparency and quality governance. The Chinese's contribution to illegal mining, which is locally known as galamsey has been a major challenge facing Ghana government. The minister of information, Mustapha Hamid in an interaction with the Chinese ambassador warned that all Chinese nationals will be severely punished by the law should they be found linked to the menace of illegal small scale mining ${ }^{3}$.

\section{Literature Review}

There have been numerous studies done by many research on the account of China's outward foreign direct investment in Africa and other part of the world using diversified approaches attaining different outcomes. However, only a few researchers have focused on Chinese investment in Ghana. This literature review is set to explore the major research works done on China's investment specifically to Ghana. Kwasi and Li (2016) Considering China's contribution to the development process in Ghana through foreign direct investment, provision of financial aids has increased management training skills, and the transfer of innovation and technological strategies. The authors examined the linked between China's foreign direct investment and Ghana's building and construction sector performance, by using the robust regression model and the outcome show that Chinese foreign direct investment in the building and construction sector of Ghana has a relevant positive effect on economic growth of Ghana as a result of a strong expansion of investors dauntless in Ghana's economy.

Joseph (2015) Chinese investment in Ghana, using the Investment Development Path (IDP) theory introduced by Dunning in 1981 to examine the basis of the Chinese Investment model, of which the author sheds light China's investment in Ghana after 2008 and the performance these investments so as briefly examines the specifics of Chinese investment in Ghana.

Samuel and Nubuor (2013) a research on Chinese investment in Ghana, stating that Paris Club of donors and the international financial institutions do exert political pressure on African government for political and economic reforms, although such vigorous economic and financial cannot avoid having political repercussions whereas China exercise no political pressure on African countries. However, the author revealed that Ghana is not an exemption and hence China continues to invest in Ghana and help in the country's economic development.

Decai and Gyasi (2012) Ghana identifying foreign direct investment as a key way to transform its economic growth and as China seeking to offer Ghana a new model for developing alternative to the western style that depends on commercial relations and fair market. The focused on the impact of China Foreign Direct Investment (FDI) flows on the Ghanaian employment sector using a statistical descriptive method which supports the analysis of the influence of FDI inflow in a quantitative way. The result indicated that, about $80 \%$ or more of investments from China has been mostly concentrated in the manufacturing, building \& construction and general trade sectors of the economy of Ghana between 2006 and 2010.

Kojo (2013) examining the specificities of Chinese agricultural investments in Ghana in relation to wider investments and Chinese interests in the country. As China has rapidly emerged as the largest trading and

${ }^{s}$ https//www.yen.com.gh/amp/92772-ghana-warns-china-illegal-mining.html 
investment partner in Africa and the structure of its trade reflects the emergence of a highly sophisticated manufacturing economy which imports raw minerals, energy and primary agricultural commodities and exports manufactured goods, machinery, information and communication technologies, and construction. Chinese investments within African countries have expanded rapidly, enabling African nation states to begin to develop the beginnings of a modern infrastructure that should attract more investments.

Kwasi and Li (2017) Foreign direct investment showing a positive influence on national economic growth and advancement, examining the FDI Inflow in Ghana and the contribution of the Selected Countries observed FDI inflows between 2000 and 2014. Comparing the quantitative study using China, US, India and South Africa showed that the selected countries contributed more to the agriculture, manufacturing, building/construction, and service sectors of Ghana in terms of volumes of investments and projects as compared to other sectors of the economy due to incentives attached to prioritized economic sectors.

Many studies of China outward FDI in Ghana failed to outline the yearly number of projects by the Chinese in the Ghanaian economy. However, there is always a positive conclusion China's presence in Ghana by most authors without hammering on the negative aspect of Chinese investment in Ghana. I believe that considering both the negative and positive help to weigh the significance of the FDI component in Ghana.

\section{Data and Methodology}

This paper is being focused on the examination of Chinese foreign direct investment inflow into Ghana's economy. The paper makes use of the quantitative analysis through a descriptive statistical approach. Since China's FDI forms part of the overall FDI in Ghana which goes into all the various sectors of the Ghanaian economy. By considering the total number of registered projects recorded through FDI between 2013 and 2018. I separated the number of Chinese foreign direct investment from the overall registered projects established by foreign investing nations. The value (the estimated cost of projects) was also taken into account. The study also makes use of data from the quarterly investment reports generated from the Ghana Investment Promotion Centre the sole organization formed by the government mandated to regulate, promote and foster investment inflows and the wellbeing of investors.

\section{Registered Chinese Projects in Ghana}

From 1994 September to December 2009 the total registered projects from foreign countries was 3,214. Out of the 3214 China had the largest registered projects in Ghana with a total 415. However, these Chinese registered projects were distributed among all the sectors in the Ghanaian economy. Agriculture 8, building and construction 20 projects, export trade 7 projects, general trading 103 projects, Liaison 7 projects, manufacturing 145 projects, service 66 projects and tourism 59 projects. However, there have been 182 registered projects by the Chinese in the Ghanaian economy from 2013 to 2018. Conversely, a total of 1,311 foreign direct investment projects were registered between 2013 and 2018 of which 418 projects were recorded in 2013,183 projects in 2014, 170 projects in 2015,180 projects in 2016, 192 and 168 projects in 2017 and 2018 respectively. The Table 1 shows breakdown of the registered projects.

Table-1. Chinese registered projects between 2013 and 2018

\begin{tabular}{|c|c|c|}
\hline Year & Number of projects & Cost of projects (US\$M) \\
\hline 2013 & 34 & 41.91 \\
\hline 2014 & 15 & $1,609.92$ \\
\hline 2015 & 22 & 172.2 \\
\hline 2016 & 36 & 301.52 \\
\hline 2017 & 38 & 232.93 \\
\hline 2018 & 37 & 159.3 \\
\hline Total & 182 & $2,517.78$ \\
\hline
\end{tabular}

From the Table 1 the data collection were based on the quarterly reports by the Ghana Investment Promotion Centre. However, there was no data for registered projects by China and the estimated cost of projects in the third quarter of 2013 whereas there were no records on the number of registered projects for the second quarter of 2014. China registered one project in the second quarter of 2015 but there was no record on the estimated cost of the project as it was not captured by the GIPC as it was not ranked among top ten (10) investment cost of projects.

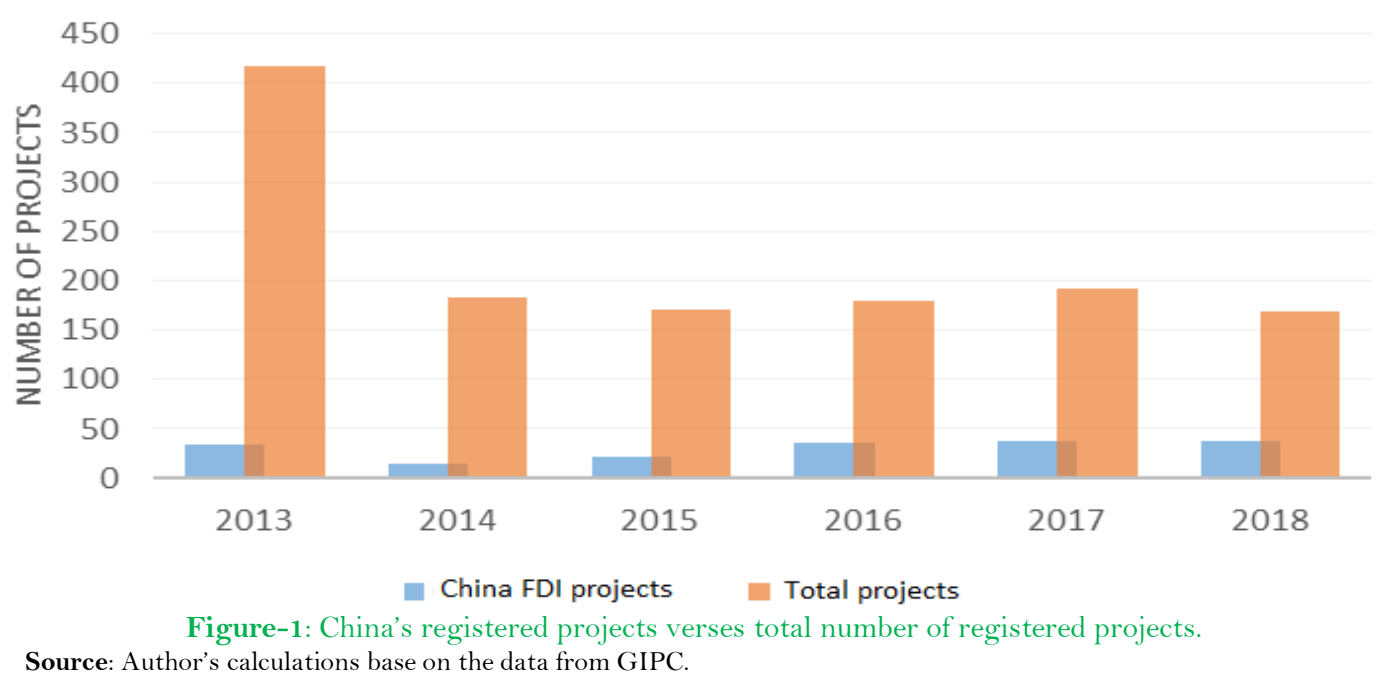


The total estimated cost of the total foreign direct investment registered projects between 2013 and 2018 amounted to US $\$ 19,930.03$ million of which the breakdown was as follows 4,261.22million in 2013, US\$3,121.45 million in 2014, US $\$ 2,680.60$ million in 2015, US $\$ 2,433.50$ million in 2016, US\$3,562.50million in 2017 and US\$2,870.76million in 2018. China's cost of registered projects percentage, share on the yearly accumulated total cost of projects are as follow $0.98 \%$ in $2013,51.57 \%$ in $2014,6.42 \%$ in $2015,12.39 \%$ in $2016,6.53 \%$ in 2017 and $5.55 \%$ in 2018 . The Figure 2 indicates total cost of projects, verses cost of China's registered projects.

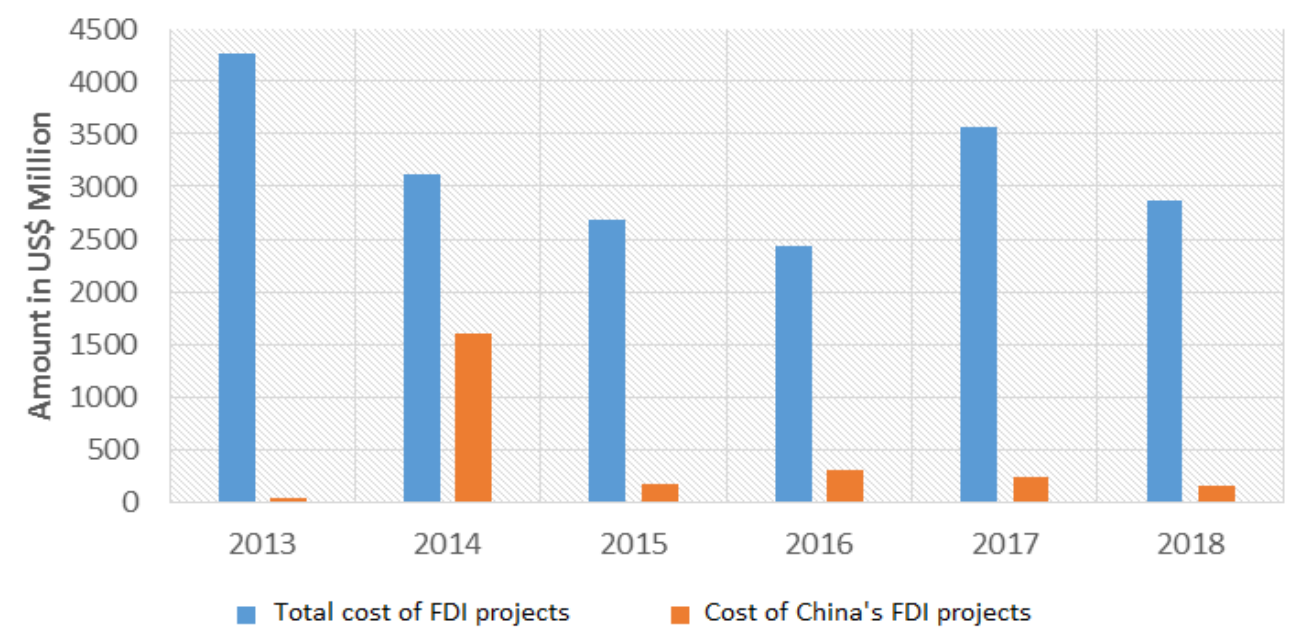

Figure-2. FDI total cost of projects verses cost of China's registered projects.

Source: Author's calculations base on the data from GIPC.

\section{Discussions}

Ghana's investment environment has been very conducive for Chinese investment and other top investing countries. The effect and implication of China-Ghana trade and investment are diverse. Employment of skilled and unskilled workforce has been an ultimate significant factor when considering the investment environment in Ghana. Experts and technology transfer has been readily available to the various sectors of the Ghanaian economy to employ experienced workers. On the other hand, it is clear that the number of registered foreign direct investment projects in Ghana by the Chinese is significantly lower than the amount Ghana's outward foreign direct investment in China. Ghana and most African countries are faced with international trade deficits and are not benefiting from slang break of trading with China. Major Chinese investment are found in the manufacturing sector of the Ghanaian economy which turns to increase a stiff competition from giant Chinese manufacturing companies. Ghana export raw materials to China and imports over $60 \%$ of manufactured product China. With Ghana's exportation mainly being raw materials and other resources turns to put its economy at risk. The commodity price shock of 1999 is a clear example - between 1998 and 2000, a fall in world commodity prices affected the economy with a negative $20 \%$ drop in Ghana's GDP growth rate (IMF, 2012). However, with the current government agenda of one-district-one factory initiative which aims at transforming Ghana's economy into an industrial economy should set out policies and regulations to protect these infant industries in all the sectors.

\section{Conclusion}

Regardless of external and internal factors affecting foreign direct investment inflows in Ghana, Ghana continue to provides sound business and investment-friendly environment for both domestic and foreign investment of which Chinese investors do benefit from it. Foreign direct investment inflows in Ghana has been growing significantly every year as Ghana reached the major recipient of FDI ahead of Nigeria in 2018. The investment motives which is set to be achieved by foreign investors should be a major concern by the host countries on the African continent as there might be a hiding agenda beyond the normal investment motives. Objective which focuses on Chinese foreign direct investment, its benefit and issues on Ghana's economy was achieved after considering China's contribution to the registered projects and other wide range of development packages to Ghana. This may not be adequate to capture the number of employments and impact of the third quarter of 2013, second quarter of 2014. However, Ghana's longstanding bilateral relationship in the aspect of investment and trade in recent year has brought many developments to both nations.

\section{References}

ACET, 2009. Looking east: China-Africa engagements. Ghana country case study. Accra: African Center for Economic Transformation. Alfred, A., 1967. Politics among nations: The struggle for power and peace. 4th Edn., New York: Knopf.

Broadman, H., 2007. Africa's silk road: China and India's new economic frontier. Washington: The World Bank.

Claassen, C., L. Elsabe and H. Bezuidenhout, 2012. Chinese foreign direct investment in Africa: Making sense of a new economic reality. African Journal of Business Management, 6(47): 11583-11597.Available at: https://doi.org/10.5897/ajbm12.279.

Davies, M., H. Edinger, N. Tay and S. Naidu, 2008. How China delivers development assistance to Africa, Centre for Chinese Studies, University of Stellenbosch, issue no.1. pp: 38.

Decai, T. and K. Gyasi, 2012. China-Africa foreign trade policies: The impact of China's foreign direct investment (FDI) flow on employment of Ghana. Energy Procedia, 16: 553-557.Available at: https://doi.org/10.1016/j.egypro.2012.01.089.

Dunning, J., 1993. Multinational enterprises and the global economy. Massachusett: Addison-Wesley Publishing.

Ghana Investment Promotion Centre, 2012. Press Release for First Quarter Investment Report, 8(1). Available from https://www.gipcghana.com/press-and-media/downloads/reports.html.

IMF, 2012. World economic outlook: Growth resuming, dangers remain. Washington DC: International Monetary Fund.

Joseph, Y.A., 2015. Chinese investment in Ghana. Argumenta Oeconomica Cracoviensia(13): 61-81.Available at: https://doi.org/10.15678/aoc.2015.1304.

Kojo, S., 2013. Expanding agribusiness: China and Brazil in Ghanaian agriculture. IDS Bulletin, 44.4. Available from http://onlinelibrary.wiley.com/journal/10.1111/(ISSN)1759-5436/issues. 
Kwasi, B.-G. and Y. Li, 2016. The linkage between China s foreign direct investment and Ghana s building and construction sector performance. Eurasian Journal of Business and Economics, 9(18): 81-97.Available at: https://doi.org/10.17015/ejbe.2016.018.05.

Kwasi, B.G. and Y. Li, 2017. FDI trends in Ghana: The role of China, US, India and South Africa. Eurasian Journal of Economics and Finance, 5(2): 1-16.Available at: https://doi.org/10.15604/ejef.2017.05.02.001.

OECD, 2006. African Economic Outlook 2005-2006. Available from www.oecd.org/dev/publications/africanoutlook.

Reuters, 2007. Experts warn Ghanaian dam puts hippos at risk. Available from https://www.reuters.com/article/us-ghana-dam/expertswarn-ghanaian-dam-puts-hippos-at-risk-idUSL261043920070926.

Samuel, K.F. and S.A. Nubuor, 2013. Research on the Chinese investments in Ghana. Journal of Economics and Sustainable Development, $4(4): 118-124$.

Sir, W.R., 1829. A discourse of the invention of ships, anchors, compass, \& c. The Works of Sir Walter Ralegh, Kt. (1829, reprinted 1965), 8: 325.

UNCTAD, 1998. World investment report 1998: Trends and determinants. New York and Geneva: United Nations Conference on Trade and Development.

Unctad, 2007. Asian foreign ddirect investment in Africa: Towards a new Era of cooperation among developing countries. UNCTAD/ITE/IIA/2007/1. Available from https://unctad.org/en/Docs/iteiia20071_en.pdf. 